\title{
Health promoting and sensory properties of phenolic compounds in food
}

\author{
Lívia de Lacerda de Oliveira ${ }^{1}$, Mariana Veras de Carvalho², Lauro Melo ${ }^{3}$ \\ http://dx.doi.org/10.1590/0034-737X201461000002
}

\begin{abstract}
Phenolic compounds have been extensively studied in recent years. The presence of these compounds in various foods has been associated with sensory and health promoting properties. These products from the secondary metabolism of plants act as defense mechanisms against environmental stress and attack by other organisms. They are divided into different classes according to their chemical structures. The objective of this study was to describe the different classes of phenolic compounds, the main food sources and factors of variation, besides methods for the identification and quantification commonly used to analyze these compounds. Moreover, the role of phenolic compounds in scavenging oxidative stress and the techniques of in vitro antioxidant evaluation are discussed. In vivo studies to evaluate the biological effects of these compounds and their impact on chronic disease prevention are presented as well. Finally, it was discussed the role of these compounds on the sensory quality of foods.
\end{abstract}

Key Words: analytical methods, antioxidants, health promoting properties, sensory properties.

\section{RESUMO}

\section{Propriedades de saúde e sensoriais de compostos fenólicos em alimentos}

Os compostos fenólicos têm sido extensivamente estudados nos últimos anos. A presença destes compostos em vários alimentos tem sido associada com as propriedades de saúde e sensoriais. Estes produtos do metabolismo secundário de plantas atuam como mecanismos de defesa vegetal contra o estresse ambiental e ataque de outros organismos. Esses compostos são divididos em diferentes categorias de acordo com as suas estruturas químicas. Este estudo teve como objetivo descrever as diferentes classes de compostos fenólicos, as principais fontes alimentares e fatores de variação, além de métodos para a identificação e quantificação comumente usados para analisar estes compostos. Além disso, discute-se o papel de compostos fenólicos no combate ao estresse oxidativo e as técnicas de avaliação da atividade antioxidante in vitro. Estudos in vivo para avaliar os efeitos biológicos destes compostos e seu impacto na prevenção de doenças crônicas também são apresentados. Por fim, foi discutido o papel desses compostos sobre a qualidade sensorial dos alimentos.

Palavras-Chave: métodos analíticos, antioxidante, propriedades de saúde, propriedades sensoriais.

Recebido para publicação em 15/08/2014 e aprovado em 23/10/2014

${ }^{1}$ Food Engineer, PhD. Department of Nutrition. University of Brasilia, 70910-900, Brasilia, Distrito Federal, Brazil. liviapineli@unb.br (corresponding author).

${ }^{2}$ Nutritionist, Master of Science. University of Brasilia, 70910-900, Brasilia, Distrito Federal, Brazil. mariana.carvalho@ifb.edu.br

${ }^{3}$ Food Engineer. Doctor of Science. Department of Biochemical Engineering School of Chemistry, Federal University of Rio de Janeiro, 21941-909, Rio de Janeiro, Rio de Janeiro, Brazil.lauro@eq.ufrj.br 


\section{INTRODUCTION}

Polyphenols are compounds of the plant secondary metabolism that can accumulate in certain plant organs such as leaves, fruits, roots and stems. As a large group of bioactive chemicals, they have diverse biological functions. Because they are essential to plant life, they can provide defense against microbiological attacks and make food unpalatable to predators and other herbivores (Vogt, 2010; Bavaresco, 2003).

The consumption of fruit and vegetables, rich in phenolic compounds, has been associated to healthy diets and to the prevention of several chronic diseases because of the antioxidant properties of these compounds, which act as reducing or metal chelating agents, hydrogen donors and singlet oxygen quenchers (Tsao \& Yang, 2003). Moreover, phenolic compounds can prevent disease through mechanisms that differ from antioxidant function, such as cellular signaling, gene expression, and modulation of enzymatic activity (Milenkovic et al., 2011).

Phenolic compounds may also affect positively or negatively the sensory characteristics of food with impacts on color, flavor and astringency. This impact needs to be evaluated and becomes important so that health-promoting products could be also palatable and largely consumed.

This paper discusses the health promoting and sensory properties of phenolic compounds in food. For this purpose, classes of phenolic compounds, their sources, the methods of determination of these compounds in food and for the determination of in vitro and in vivo antioxidant activities are discussed, as well as the role of these compounds in the sensory and functional properties of food.

\section{Classes of phenolic compounds}

Phenolic compounds are secondary plant metabolites and important determinants in the sensory and extra nutritional quality of fruits, vegetables and other plants (Lapornik et al., 2004; Ignat et al., 2011). According to Flores et al. (2014), the biosynthetic pathway of flavonoids starts with L-phenil alanine yelding cinnamic acid by a reaction of monoxidative deamination catalysed by phenylalanine ammonia lyase, which directs the carbon flow from the shikimate pathway to the various branches of the general phenylpropanoid metabolism (Vogt, 2010).

These compounds present an aromatic ring bearing one or more hydroxyl groups and their structures may range from that of a simple phenolic molecule to that of a complex high-molecular mass polymer (Balasundram et al., 2006).
Phenolic compounds comprise a wide variety of molecules that have a polyphenol structure (i.e. several hydroxyl groups on aromatic rings), but also molecules with one phenol ring, such as phenolic acids and phenolic alcohols. Polyphenols are divided into several classes according to the number of phenol rings and to the structural elements that bind these rings to one another. Although such structural diversity results in the wide range of phenolic compounds that occur in nature, they can basically be categorized into several classes (Balasundram et al., 2006). They range from simple molecules (such as phenolic acids with a single aromatic structure), biphenols (such as ellagic acid) and flavonoids, which contains 2 to 3 aromatic rings (Ignat et al., 2011) to polyphenols containing 12 to 16 rings. The main groups of polyphenols are flavonoids, phenolic acids, tannins (hydrolysable and condensed), stilbenes and lignans (Balasundram et al., 2006; D’Archivio et al., 2007).

\section{Flavonoids}

The basic flavonoid structure is the flavan nucleus, which consists of 15 carbon atoms arranged in three rings (C6-C3-C6), labeled A, B, and C (Pietta, 2000; Rice-Evans et al., 1996). Graf et al. (2005) described that the types of flavonoids differ among each other by the connection position of $\mathrm{B}$ and $\mathrm{C}$ rings, as well as the degree of saturation, oxidation and hydroxylation of the $\mathrm{C}$ ring. Based on the characteristics of the aglycones, flavonoids are divided into different subclasses (Figure 1): flavonols, flavones, flavanones, isoflavones, flavanols or flavan-3-ols, and anthocyanidins (He \& Giusti, 2010; Ignat et al., 2011). Individuals flavonoids are structurally distinct because of different patterns of hydroxylation, methylation and conjugation with various mono and disaccharides.

Flavonols are characterized by the presence of unsaturation in the heterocyclic ring, an oxygen atom in C4 and a hydroxyl group in position 3. The main components are kaempferol, quercetin and miricetin. Flavones differ from favonols by the absence of the hydroxyl group. Luteolin and apigenin are the most important phenolic compounds in this class. Flavanols or flavan-3-ols are characterized by the presence of saturated heterocyclic ring and hydroxyl in C3. Catechin, epicatechin, epigalocatechin, theaflavin are among many structures and isomers of this class. Flavanones also has a saturated three-carbon chain but a ketone group in C4 and no hydroxyl in C3. Flavanones are present in high concentrations only in citrus fruit, but they are also found in tomatoes and certain aromatic plants such as mint. The main aglycones are naringenin in grapefruit, hesperedin in oranges, and eriodictyol in lemons (Ignat et al., 2011). 
Isoflavonoids differ from the other groups because the $\mathrm{B}$ ring is bound to $\mathrm{C}-3$ in ring $\mathrm{C}$ instead of $\mathrm{C}-2$ (Erlund, 2004). Isoflavones have structural similarities to estrogens, i.e. hydroxyl groups in the C7 and C4, positions, like estradiol molecule, and they are occasionally referred to as "phytoestrogens" (Klejdus et al., 2007; D’Archivio et al., 2007).

Anthocyanins differ from other flavonoid classes by the oxidation state to flavilium salt. They are watersoluble vacuolar pigments that may appear as red, purple or blue depending on the $\mathrm{pH}$ (Ignat et al., 2011). When the anthocyanidins are found in their glycoside form (bonded to a sugar moiety), they are known as anthocyanins (Castañeda-Ovando et al., 2009). There is a a substantial variety of anthocyanins spread in nature. The main differences between them are the number of hydroxylated groups, the nature and the number of bonded sugars to their structure, the aliphatic or aromatic carboxylates bonded to the sugar in the molecule and the position of these bonds (Kong et al., 2003; Castañeda-Ovando et al., 2009). The sugars commonly linked to anthocyanidins are monosaccharides (glucose, galactose, rhamnose and arabinose), and di- or tri-saccharides formed by the combination of the four monosaccharides (Bureau et al., 2009). So far, there are reports of more than 600 different anthocyanins (Konczak \& Zhang, 2004) and 23 anthocyanidins (Andersen \& Jordheim, 2006; Kong et al., 2003; Rein, 2005).

\section{Non-flavonoids}

As shown in Figure 2, non-flavonoids include phenolic acids, tannins, stilbenes and lignans (Horst and
Lajolo, 2007). Phenolic acids are phenols with one carboxylic acid functionality. When describing plant metabolites, it refers to a distinct group of organic acids. These naturally occurring phenolic acids contain two distinguishing constitutive carbon frameworks: the hydroxybenzoic and hydroxycinnamic structures (Robbins, 2003). These compounds exist predominantly as hydroxybenzoic and hydroxycinnamic acids that may occur either in their free or conjugated form (RazzaghiAsl et al., 2013).

Hydroxybenzoic acids have the C6-C1 structure in common. The dihydroxybenzoic acid derivatives show an antioxidant response dependent on the relative positions of the hydroxyl groups in the ring (Rice-Evans et al., 1996). There are commonly four different kinds of phenolic acids of this category: gallic, phydroxybenzoic, protocatechuic, syringic and vanillic acids, which may be present in soluble form combined with sugars or organic acids, as well as bound fractions of the cell walls, as in lignin (Schuster \& Herrmann, 1985; Strack, 1997; Häkkinen, 2000; Koseki et al., 2010). Benzoic acid and salicylic acid (2-hydroxybenzoate) are also commonly found.

Hydroxycinnamic acids are phenolic acids with C6C3 chain. They occur in various conjugated forms such as esters of hydroxy acids, i. e., quinic, shikimic and tartaric, besides derivatives of sugars. The free forms are the result from chemical and enzymatic hydrolysis during extraction of plant tissue (Schuster \& Herrmann, 1985; Macheix et al., 1990; Naczk \& Shahidi, 2004). Caffeic, ferulic, p-coumaric and sinapic acids are hydroxycinnamic acids widely found in food (Bravo, 1998; Macheix et al., 1990).

Flavonoids

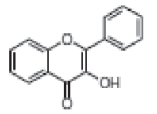

Flavonols

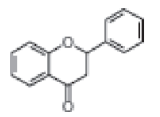

Flavanones

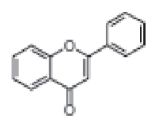

Flavones

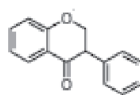

Isoflavones
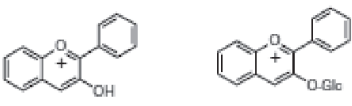

Anthocyanidins and Anthocyanins
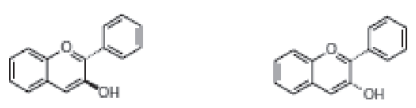

Trans and cis - Flavan-3-0ls (flavanols)

Figure 1. Basic structures of flavonoids. 
Gallic acid, 3,4,5-trihydroxybenzoic acid, takes part in the formation of hydrolysable gallotannins (Haslam, 1982; Haddock et al., 1982; Strack, 1997). The product of their dimeric condensation (hexahydroxydiphenic acid) and the corresponding dilactone, ellagic acid, are common metabolites of plants. Ellagic acid is commonly present in ellagitannins, such as the analogs of diphenics linked to glucose esters (Landete, 2011). In nature, ellagic acid exists in the free and complexed forms as easily hydrolysable ellagitannins (Whitley et al., 2003).

Tannins are water-soluble phenolic compounds with high molecular weights. They are known as proanthocyanidins, as they may give rise to anthocyanidins when their structures are cleaved by oxidative cleavage. Tannins can precipitate alkaloids, gelatin and other proteins (Bate-Smith \& Swein, 1962) and can be subdivided into hydrolysable and condensed tannins (Porter, 1989). Proanthocyanidins (condensed tannins) are polymeric flavonoids. According to Ignat et al. (2011), the most widely studied condensed tannins are based on flavanols (")-epicatechin and (+)catechin, or on flavan-3,4-diol, as leucocyanidin (Battestin et al., 2004).
Stilbenes contain two phenyl moieties connected by a two-carbon methylene bridge (C6-C2-C6). The most extensively studied stilbene is resveratrol (Pandey \& Risvi, 2009, Lee \& Rennaker, 2007). Several plant species are known to produce resveratrol, such as vine plant, peanut and berries. In grapes, resveratrol $(3,5,4$ 'Trihydroxystilbene) is a phytoalexin produced in huge amount in grapevine skin in response to infection by Bothrytis cinerea (Delmas et al., 2006).

Lignans are phytoestrogens present in seeds, vegetable oils, cereals, legumes, fruits and vegetables as aglycones, glycosides, esterified glycosides or as biooligomers (Gerstenmeyer et al., 2013), structurally characterized by the coupling of two phenylpropanoid units by a bond between the $\beta$-positions in the propane side chains (Willfor et al., 2006). The units are treated as propylbenzene units, giving the positions 8 and 8 ' to these linked carbon atoms. They possess an enormous structural diversity originating from various linkage patterns (Tsopmo et al., 2013). Frequently occurring lignans are lariciresinol, pinoresinol, secoisolariciresinol, syringaresinol, matairesinol, 7hydroxymatairesinol, sesamin, sesamolin and sesamol (Gerstenmeyer et al., 2013).

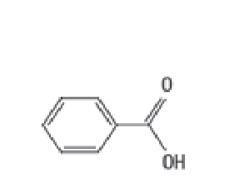

Hydroxybenzoic acids

Biphenols

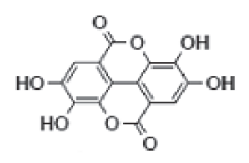

Ellagic acid

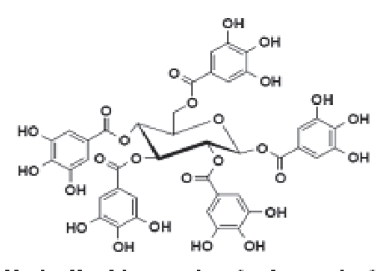

Hydrolisable tannins (galotannins)

\section{Non-flavonoids} Phenolic acids
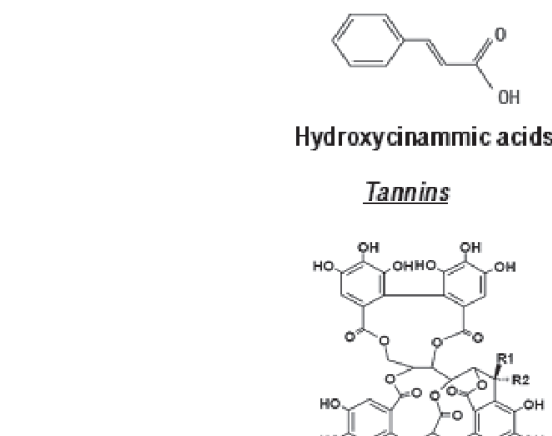

Hydroxycinammic acids

Tannins

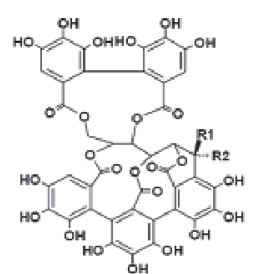

Hydrolisable tannins (ellagitannins)

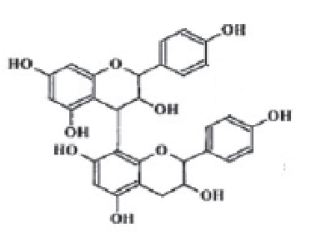

Condensed tannins (proanthocyanidins, e.g. procyanidin dimer)

Other non-flavonoid pohphenols
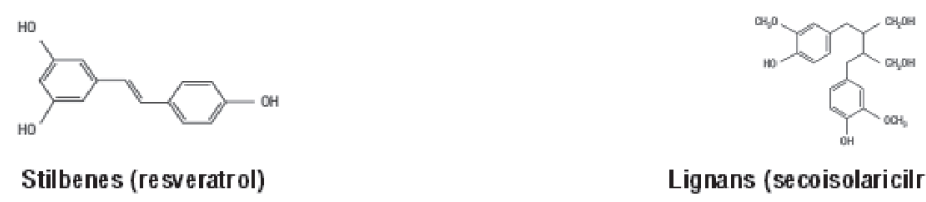

Lignans (secoisolaricilresin ol)

Figure 2. Basic structures of non-flavonoid phenolic compounds. 


\section{Sources, databases and factors that influence composition of phenolic compounds}

The United States Department of AgricultureAgricultural Research Service have recently updated his USDA Database for the Flavonoid Content of Selected Foods (AgricRes Serv, 2013), a document that contains values of 506 food items for five of six subclasses of flavonoids: flavonols, flavones, flavanols, flavanones and anthocyanidins. According to the database, the main sources of flavonols are capers, licorice roots, dill weed, onions, berries, ginger, fennel leaves, kale, watercress, okra, peppers, parsley, safron, radish, broccoli, chia seeds, some beans and buckwheat. Flavones are found in sorghum, some spices and herbs such as oregano, peppermint, celery seed, safron and dried parsley, juniper berries, kumquats, saw-thistle, artichokes, celery, peppers, radicchio, and vinespinach. Sources of flavanols are apple skin, banana, some berries, red wine, Camelia sinensis teas (black, green, white), black grapes, nectarine, whole peaches, black diamond plums, broadbeans and pecan nuts. Flavanones are found mainly in citrus (orange, grapefruit, lemon kumquats) and their juices, and the main sources of anthocyanins are berries, grapes, red wine, cherries, currants, jambul, plum, acerole, red cabbage, eggplant, red onions, radicchio, radishes, pecan nut, pistachio nut, black and red beans, and purple wheat.

Regarding non-favonoid sources, phenolic acids are commonly found in many food (Rothwell et al., 2013), but special attention is given in recent literature for wine (Gonçalves et al., 2013), coffee (Marmet et al., 2014; Baeza et al., 2014), potatoes (Narváez-Cuenca et al., 2013), citrus (He et al., 2011), olive (Ballus et al., 2014; Franco et al., 2014) and grains (Gallardo et al., 2006; McCarthy, 2012). According to USDA Database for the Proanthocyanidin Content of Selected Foods 2004 (AgricResServ, 2004), tannins are mainly found in wine, tea, barley, sorghum, buckwheat, some beans, cacao, nuts, cinnamon, apples, some berries and at a small extent, some other fruits such as avocado and apricot. Soybean and its derivatives are the most important sources of isoflavones (Graf et al., 2005; AgricResServ, 2008). Linseeds and sesame seeds seem to be the richest dietary sources of lignans (Smeds et al., 2007). Strawberries and other berries are a widely studied source of ellagitannins and ellagic acid (Seeram et al., 2006; Pineli et al., 2011a; b; 2012; Pinto et al., 2008, 2007). For additional information about contents of the various classes of phenolic compounds on over 400 different food, Phenol-Explorer is also recommended (Rothwell et al., 2013).

The role of these metabolites is to protect plants against biological and environmental stresses, therefore they are synthetized in response to fungal, bacterial infections, exposure to high radiant energy or prolonged exposure to ultraviolet radiation (Crozier et al., 2000; Bravo, 1998) and their production result from complex interactions between biosynthesis, transport, storage and degradation of these molecules (Dixon \& Paiva, 1995). Each of these processes is ruled by genes and therefore influenced by heredity (cultivar), ontogeny (developmental stage of the plant and fruit) and by the environment (Robbers et al., 1996). Significant differences in total phenolic and flavonoid composition were found by Pinto et al. (2008) and Cordenunsi et al. (2005) among cultivars of strawberries produced in the state of São Paulo. Santos (2007) reports that the paths of secondary metabolites are activated only in some particular developmental stages or periods of stress caused by nutrient limitation or microbiological attack.

The type of farming, the attack by pests and parasites, the cultural practices, the incidence of light and the environment temperature are some of the important factors in the pre-harvest phase (Dixon \& Paiva, 1995). The synthesis of flavonoids is accelerated by light. Consequently, in plants grown in greenhouses, where UV rays are blocked, the content of flavonoids is reduced. Vegetables grown in Spain or South Africa contain 4-5 times more flavonoids than those grown in the UK (Aherne \& O'Brien, 2002; Burns et al., 2001; Sellappan et al., 2002). Pineli et al. (2011a) demonstrated that the degree of maturation influenced the phenolic content and antioxidant activity in strawberries. Ripe fruit showed the lowest levels of phenolics. Pineli et al. (2011b) studied the composition of antioxidants in strawberries at three different harvest dates (May, July and September) and found that rainfall 30 days before harvest influenced negatively many phenolics and antioxidant activity of strawberries harvested in May. In July, when photoperiod is longer and temperature is lower, at 30 days before harvest probably led to higher antioxidant activity and vitamin C. Increased photoperiod and temperature at the final stage of maturation seem to increase the amount of pigments and free ellagic acid in strawberries.

\section{Methods of determination of phenolic compounds}

The Folin-Denis (Folin \& Denis, 1912) method is the most adopted for analysis of total phenolic compounds in plant material. The Folin Denis or Folin Ciocalteu reagent consists of sodium tungstate, phosphomolybdic acid and ortho phosphoric acid. The reduction of the phosphotungstic and phosphomolybdic acids, resulting in a blue colored complex in alkaline solution, occurs in the presence of phenolic compounds. Singleton \& Rossi (1965) modified this method for analysis of phenolic compounds, as this was submitted 
to precipitation that interfered with colorimetric reading. However, the new method is still subjected to interference of antioxidants such as ascorbic acid and sulfite, especially if they are in high amounts in relation to the contents of phenolics. In addition, high concentrations of sugars lead to the formation of reactive reductones in the alkaline solution, particularly if heated, and also aromatic amines can react with phenols (Singleton, 1974). This method is very sensitive to reduction by phenols. The number of hydroxyl and of potentially oxidizable groups controls the intensity of the color. The phenolic group must be in the form of phenolate so that molibde and tungstofosfate anions can produce oxidation (Ough \& Amerine, 1988).

The analysis of total flavonoids is based on the reaction of these compounds with aluminum chloride. The aluminum cation form stable complexes with flavonoids in methanol, occurring in spectrophotometric analysis a shift to longer wavelengths and an intensification of absorbance. Thus, it is possible to determine the amount of flavonoids, avoiding the interference of other phenolic substances, mainly phenolic acids, which invariably come with flavonoids in plant tissues (Schmidt \& Gonzalez-Ortega, 1993).

Methods for analysis of anthocyanins require previous extraction of anthocyanins from the food matrix. At low $\mathrm{pH}$, anthocyanins are predominantly in the form of flavylium cation, which shows red color in aqueous solution. The fact that the flavylium cation is stable in acidic $\mathrm{pH}$ led to the use of solvents containing mineral or organic acid in the extraction of anthocyanins from fruit and vegetables (Macheix et al., 1990). Quantification is based on the extinction coefficient $(\varepsilon)$ of the predominant monomeric anthocyanin in each food.

The method of vanillin (Broadhurst \& Jones, 1978) is specific to a limited class of phenolic compounds, which have a single bond in the 2,3-position and hydroxyl groups in alternating positions on the ring. In this method, both the leucoanthocyanidins (catechins) and proanthocyanidins (condensed tannins) react with vanillin in the presence of $\mathrm{HCl}$, to produce a red condensation product, which is detected spectrophotometrically (Agostini-Costa et al., 2003).

The acidified butanol method used for quantification of proanthocyanidins was described by Porter et al. (1986). Highly selective for the analysis of condensed tannins, it is based on the oxidative cleavage resulting in anthocyanidins, red in acid medium. Color development is dependent on the solvent and is reduced by the presence of water, and the reaction conditions need to be strictly controlled (Agostini-Costa et al., 2003). As commercial tannic acid and catechin do not show a positive response to this reaction, the condensed tannin must be purified in the laboratory to be used as standard (Agostini-Costa et al., 2003).

Reverse phase liquid chromatography is currently applied for the analyses of flavonoids. Comparison between UV spectra and retention times and those of standards are used for identification. Quantification is done by using known concentrations of external standards from the commercial source (Vanamala et al., 2006, Girennavar et al. 2008,Pinto et al., 2008, Pineli et al., 2011a, 2011b, 2012, Bautista-Ortín et al., 2014).

Liquid chromatography associated to mass spectrometry (MS or MS/MS) methods, with ionization techniques of electrospray ionization (ESI), and matrixassisted laser desorption / ionization (MALDI), and time of flight (TOF), ion trap (IT) or quadrupole time of flight (QTOF) techniques of mass selection, have been developed, separately or in association to Nuclear Magnetic Ressonance (NMR) to elucidate structures. For example, LC-ESI-MS methods, combined or not with DAD spectra evaluations, were applied by Tarascou et al. (2011) and Simirgiotis et al. (2013) for fruit and by Bajoub et al. (2015) for olive oil. Koolen et al. (2013), Yildirim \& Turker (2014) and Rodríguez-Rivera et al. (2014) developed LC-ESI-MS/MS techniques to identify more accurately structures of phenolics in fruit, whereas Marmet et al. (2014) used the same method to analyse phenolics in human plasma after the consumption of coffee. It is also reported the use of LC-ESI-TOF-MS by Ouni et al. (2011) to characterize phenolics of olive oils from different geographical origins, LC-ESI-QTOFMS for the analysis of globe artichoke by Ibrahim et al. (2013) and of LC-ESI-IT-TOF-MS for determination of phenolic compounds of walnuts by Grace et al. (2014). LC-MS and NMR were used together for the analyses of litchi leaf by Wen et al. (2014) and of lychee pulp by $\mathrm{Su}$ et al. (2014). Tannins of root bark had their structures characterized by MALDI TOF and NMR in the study of Abdalla et al. (2014) and for structural characterization of phenolic compounds from cold-pressed Perilla frutescens seed flour in the study of Zhou et al. (2014).

Finally, a new application of the non destructive Near Infrared spectroscopy (NIR) in the study of antioxidants content and activity, using PCA or PSLR models to simplify or dimensionally to reduce the data set to fewer independent parameters, helping interpretation, is discussed by Lu et al. (2011).

\section{Oxidative stress and methods to determine in vitro and in vivo antioxidant activity}

According to Sies (2000), oxidative stress is defined as an imbalance between oxidants and antioxidants in favor of the former, which may lead to damage. Under normal circumstances, there is a balance between the 
generation or concentration of free radicals and its removal by antioxidants (including the ability of cells to repair oxidative damage).

Many diseases and pathological conditions are associated with an increased generation of free radicals or reduction of antioxidant capacity or both conditions. Mateos et al. (2005) reported that the cytotoxicity and mediated lipid peroxidation are associated with cellular aging and chronic diseases. Oxidative stress cause damage to all types of biomolecules, including DNA, proteins and lipids. The main target of oxidative stress may vary depending on the cell type, on the type of exposure and on the severity of the stress (Fridovich, 1998). Therefore, the balance between oxidants and antioxidants may be the threshold between health and chronic disease and other pathological conditions, such as neurological diseases, inflammation, atherosclerosis, diabetes and carcinogenesis (Büyükbalci \& Nehir 2008; Halliwell, 2007; Rahman et al., 2006; Vattem \& Shetty, 2005).

The antioxidant potential of fruit and vegetables can be measured in vitro by several methods. There is not a method that can completely evaluate the total antioxidant activity of a sample, as there are many antioxidant mechanisms as the scavenging of radical, reductive ability, the complexation of metal ions, among others (Vedana, 2008). It is difficult to compare the methods, because of the complexity and different principles of reactions. Some antioxidants methods produce different or even contradictory results, making it impossible any comparison between them (Vedana, 2008; Alonso et al., 2002.). By analyzing the in vitro antioxidant potential of a food, the application of more than one method is recommended (Aruoma, 2003; Capocasa et al., 2008). Oxygen Radical Absorbancy Capacity - ORAC (Cao et al., 1993) and Total Peroxyl Radical Trapping - TRAP (Wayner et al., 1985; Siger et al., 2002) techniques are based on the inhibition of peroxy-radical-induced by oxidation, involving hydrogen donation from antioxidant molecules. Metal reducing power by single electron transfer methods include Ferric Reducing Antioxidant Power- FRAP (Benzie \& Strain, 1996) and CupricReducing Antioxidant Power - CUPRAC (Apak et al., 2004). Direct free radical inhibition by single electron transfer is the basis of 2,2-azinobis 3ethylbenzothiazoline-6-sulfonate, diammonium saltABTS Miller \& Rice-Evans, (1997), or 2,2-diphenyl-1picrylhydrazyl - DPPH (Brand-Willians et al., 1995) assays. Thiobarbituric Acid Reactive Substances TBARS assay (Podsêdek et al., 2003) is based on quantification of the products formed during lipid peroxidation. Another method involves the mechanism of oxidation and co-oxidation of beta-carotene / linoleic acid (Miller, 1971).
Recently the USDA ORAC Database for Selected Foods (AgricResServ, 2007) has been withdrawn from the website of USDA's Nutrient Data Laboratory (NDL). There is mounting evidence that the values indicating antioxidant capacity have no relevance to the effects of specific bioactive compounds, including polyphenols on human health. According to AgricResServ (2010), the associated metabolic pathways are not completely understood and non-antioxidant mechanisms, still undefined, may be responsible for that.

Due to the increasing evidence that antioxidant molecules in food have a wide range of functions, many of which are unrelated to the ability to absorb free radicals, in the last few years, biological activity of phenolic compounds have attracted great attention and health properties, such as anti-inflammatory, anti-tumour or anti-atherogenic activities are being elucidated (García-Lafuente et al., 2014).

Millenkovich et al. (2011) showed that regular consumption of orange juice or purified hesperidin for four weeks altered leukocyte gene expression in leukocytes to an anti-inflammatory and anti-atherogenic profile in humans, by inducing changes in expression of 3,422 genes, while hesperidin intake modulated the expression of 1,819 genes. Many of these genes are implicated in chemotaxis, adhesion, infiltration and lipid transport, suggesting lower recruitment and infiltration of circulating cells to vascular wall and lower lipid accumulation.

García-Lafuente et al. (2014) investigated the antiinflammatory activity of phenolic rich extracts obtained from red beans and white beans. They used a mouse macrophage cell line RAW 264.7 stimulated with lipopolysaccharide (LPS) as an in vitro model. LPS activate macrophages to produce a variety of proinflammatory cytokines such as tumour necrosis factora (TNF- $\alpha$ ). Stimulation of macrophages with LPS induced a high production of nitric oxide (NO) by the inducible enzyme nitric oxide synthase (iNOS). Bean extracts were able to reduce the production of $\mathrm{NO}$ in macrophages stimulated with LPS through the inhibition of iNOS mRNA expression. Phenolic rich extracts from beans inhibited the expression of IL-1b, IL-6 and TNF$\alpha$ genes of stimulated macrophages RAW 246.7, where red beans show more activity than white beans. The authors explained this difference of performance based on an individual profile of phenolic compounds: phenolic acids as the predominant components in white bean extracts, whereas red bean extracts presented mainly catechin derivatives, proanthocyanidins and catechin glucoside.

Mujic' et al. (2011) examined the ability of chestnut extracts to alleviate oxidative stress and to protect 
insulin-secreting pancreatic Rin-5F cells against STZinduced toxic mechanisms. STZ is a diabetogenic agent streptozotocin (STZ). The STZ treatment significantly increased the level of lipid peroxidation. Lipid peroxidation was 2.1 to 3 times lower in cells treated with extracts of chestnut. The chestnut extracts increased cell viability by protecting DNA from oxidative damage and by enhancing the natural antioxidant system. Moreover, the chestnut extracts had a significant impact on the cell's redox-status and were capable of inhibiting lipid peroxidation.

Ding et al. (2014) also studied the effect on phenolics in diabetes. Diabetic peripheral neuropathy (DPN) is the most common and problematic complication of type 2 diabetes mellitus. Recent findings reveal an important role of endoplasmic reticulum stress in the development of DPN and identify a potential new therapeutic target. Schwann cells (SC), the myelinating cells in peripheral nervous system, are highly susceptible to endoplasmic reticulum homeostasis. The study was performed in rats made type 2 diabetic with low-dose of streptozotocin and a high-carbohydrate/high-fat diet and in rat SC cultured in serum from type 2 diabetic rats. Diabetic rats showed a typical characteristic of type 2 diabetics and reducing nerve conduction velocity in sciatic/tibial nerves. The administration of grape seed proanthocyanidins significantly decreased the lowdensity lipoprotein level and increased nerve conduction velocity in diabetic rats. Moreover, grape seed proanthocyanidins or their metabolites partially prevented cell injury, and endoplasmic reticulum stress in animal and cell culture models. Prophylactic grape seed proanthocyanidins treatment might have auxiliary preventive potential for DPN partially by alleviating endoplasmic reticulum stress. After a 16-week treatment, the score of beta-cell function and the abnormal oral glucose tolerance of diabetic rats were partially reversed by grape seed proanthocyanidins treatment. In another work, the efficacious effect of grape seed proanthocyanidins was also manifested in the amelioration of pancreatic damage and endoplasmic reticulum (ER) dilatation by microscopic analyses. Moreover, grape seed proanthocyanidins treatment increased normal insulin content and decreased the number of apoptotic cells in diabetic islets (Ding et al., 2013).

Noratto et al. (2014) investigated the inhibition of tumor growth and anti-metastatic effects of peach polyphenolics in vivo using a xenograft model and MDA-MB-435 breast cancer cells. Results showed that tumor growth and lung metastasis were inhibited in vivo by peach polyphenolics in a dose range of $0.8-1.6$ $\mathrm{mg} /$ day, and these effects were mediated by the inhibition of metalloproteinases (MMP) gene expression. MMP plays a key role in the development of breast cancer metastasis, vascular endothelial growth factor (VEGF) and the transmembrane protein Ecadherin, the main component of the adherent cell-cell junction of epithelial cells. Peach extracts contain a mixture of polyphenolics such as chlorogenic acid, neo-chlorogenic acid, cyaniding $3 \beta$-glucoside, quercetin $3 \beta$-rutinoside, quercetin $3 \beta$-glucoside and catechin derivatives (Noratto et al., 2009).

Leem et al. (2014) investigated the effect of naringin, a major flavonoid in grapefruit and citrus fruits, on the degeneration of the nigrostriatal dopaminergic projection in a neurotoxin model of Parkinson's disease in rat brains. The potential underlying mechanisms focusing on the induction of glia-derived neurotrophic factor (GDNF), well known as an important neurotrophic factor involved in the survival of adult dopaminergic neurons. To investigate tumor necrosis factor- $\alpha$ (TNF$\alpha$ ) expression, rats received injections of 1-Methyl-4phenylpyridinium (MPP+), a neurotoxin, which causes permanent symptoms of Parkinson's disease by destroying the nigrostriatal dopaminergic projection. The rats received naringin one day before injection and continued daily until 6 days. The results demonstrated that naringin could increase the level of GDNF in dopaminergic neurons, contributing to neuroprotection. Moreover, naringin could attenuate the level of tumor necrosis factor- $\alpha$ in microglia increased by MPP+induced neurotoxicity. These results indicate that naringin could impart to dopaminergic neurons the important ability to produce GDNF as a therapeutic agent against Parkinson's disease with anti-inflammatory effects, suggesting that naringin is a beneficial natural product for the prevention of dopaminergic degeneration in the adult brain.

\section{Sensory impact of the health promoting phenolic compounds}

It is well known that polyphenolics, apart from possessing valuable biological properties, impart a high sensory activity to foods (Troszyñska et al., 2011). Flavonoid phenols had been indicated as the main responsible for the taste of bitterness and the tactile sensation of astringency in beverages such as tea, cider, and red wine, as well as in several types of fruits, nuts, and chocolate. Excluding the caffeine bitterness in tea, the bitterness and astringency of tea and red wine are mainly given by the flavanols. Although the mechanisms through which bitter taste perception occurs are not well understood, they are the focus of intense research, and those mechanisms involve activating distinct human bitter taste receptors (Soares et al., 2013). 
Astringency can be elicited by several substances such as multivalent metallic cations (particularly aluminium salts), dehydrating agents (ethanol), mineral and organic acid and plant phenolic compounds. Polyphenolic compounds form complexes with salivary proteins, playing a role in the sensation of astringency, due to delubrication of oral surfaces (Condelli et al., 2006). For astringency, the molecular weight seems to be important for its perception and the interactions of tannins with salivary proteins result in the perception of astringency (El Gharras, 2009). This polyphenol-salivary protein interaction may form a layer that acts as a water barrier and produces a mouth-drying sensation (Fontoin et al., 2008). Astringency increases and bitterness decreases with the mean degree of polymerization (Lesschaeve \& Noble, 2005). Consequently, the astringency decrease during wine aging might be related to acid-catalysed process that lead to lower molecularweight compounds (El Gharras, 2009). The rise quality with time is frequently reported for wines, where timedependent changes in phenolic profiles are observed (Weber et al., 2013).

Unlike astringency, bitterness is a taste induced by a large range of molecules, including organic molecules, peptides, inorganic ions and salts. It has been suggested that bitter receptors could operate as heteromeric receptors in order to accommodate the diversity (Fontoin et al., 2008). Studies suggested that some polyphenols could be responsible for the bitterness of fruits, vegetables, and derived products even if they are present in very low concentrations (Soares et al., 2013).

Flavor and color are the most important factors for the selection of processed fruit derivatives by consumers. In the literature, it is stated that sweetness and bitterness are mutually suppressed in mixtures (Birch \& Ogunmoyela, 1980; Calvino et al., 1990) and astringency and bitterness tend to be perceived as negative attributes (Lesschaeve \& Noble, 2005). Health promoting benefits do not seem to be enough to change consumers' preferences for vegetables. Cox et al., (2012) found that sensory characteristics, rather than health benefit information, need to be addressed in order to increase the popularity of Brassica vegetables. Only for responses to one vegetable (the least liked Brussels sprouts) did the health information have a small influence.

Therefore, the study of the sensory properties of polyphenolic compounds is an important subject that reflects on consumers' food choices. On the other hand, although bitterness in foods is usually unpleasant, there are some food products such as red wine and beer in which a sensory characteristic is desired (Soares et al., 2013).
Particular structures are reported to be related to polyphenols' sensory properties, including pigments (yellow, orange, red and blue) and to several compounds involved in food flavor. Many polyphenol pigments in plants are very reactive anthocyanins, yellow flavanols and flavones (El Gharras, 2009). Proanthocyanidins may play a role as co-pigments and react with anthocyanins to form new red pigments (Cadot et al., 2012). Loss or stabilization of color and increases in the the range of available hues are resulted by the conversion of anthocyanins to other compounds during food processing. Besides bitterness and astringency, some volatile polyphenols (for instance, vanillin and eugenol) are strong odorants (El Gharras, 2009). Four phenolic compounds (guaiacol, p-cresol, creosol and 2-phenylethanol) have a high odor-impact in Vanilla planifolia flavor (Dignum et al., 2004). In addition, phenolic compounds (guaiacol, creosol, p-vinyl guaiacol) were identified as key components of Tahitian vanilla flavor bringing some "smoky" notes (Brunschwig et al., 2012).

Phenolic compounds may have desired and undesired sensory properties, guiding the industrial application and food development (Laaksonen et al., 2011). Anthocyanins and flavonols can be extracted easily and safely from skin fractions of berries with aqueous ethanol. To some extent, these compounds may be added to the juice without significantly altering the sensory characteristics of it (Laaksonen et al., 2010).

The pectinolytic and hemi-cellulolytic enzymes used in blackcurrant juice production were found to increase juice yield and concentration of phenolic compounds, especially anthocyanins. Maximizing the phenolic content of the juice may contribute to negative sensory characteristics such as astringency. Therefore, it is important to control and to optimize the processing conditions (Laaksonen et al., 2012). When adding phenolic compounds using vegetal extracts in typical Spanish dry fermented sausages, sensory analyses showed no important differences between control and cocoa added products, while grape seed addition gave these products abnormal sensory profiles, demonstrating that it is possible to produce dry fermented sausages with antioxidants from vegetable extracts without affecting their sensory properties, depending on phenolic structures (Ribas-Agustí et al., 2014).

In rye grain fractions, the high phytochemical, especially phenolic content of the bran fraction, not only contributes to intense and bitter flavor but also protects it against rancidity formation during storage. It was proposed that the flavor profile and stability of certain rye products can be controlled by processing, which opens possibilities for flavor design. For example, enrichment of rye endosperm flour with rye compounds 
or fractions with antioxidant activity but with mild flavor in order to produce stable rye products without intense and bitter flavor (Nordlund et al., 2013).

During thawing of fruits, oxidation of phenolic compounds takes place and is negatively correlated with the acceptance level of fruits (Blanda et al., 2008). The higher the phenolic content of fruits after thawing, the higher the acceptance level. However, in a study comparing different pre-treating processes of strawberries, samples with the highest phenolic content were also the most pleasant ones (Blanda et al., 2009).

Agcam et al. (2014) studied the influence of a new technology on orange juice processing (pulsed electric fields, PEF, as an alternative to heat pasteurization) and found a better preservation of phenolic compounds and related this to the preservation of sensory properties. Virgin olive oil is unique among edible vegetable oils because it is consumed without any refining process that would eliminate its natural flavor, inherent part from which the bitter taste is from (Inarejos-Garcia et al., 2009). Bitterness is a characteristic sensory property of virgin olive oil, related to the presence of phenolic compounds (García-Mesa et al., 2008). In virgin olive oils, the sensory characteristics of bitterness and pungency are due to the activation of taste receptors and trigeminal nerve endings associated with taste buds in fungiform papillae, sensitive to chemical stimuli, all related to the presence of phenolic compounds. Phenolic compounds in extra-virgin olive oil are mainly aglycones and other derivatives. During the storage, the total phenols content decreases and, consequently, the typical bitter taste and pungent note of fresh extra-virgin olive oil decrease in intensity (Esti et al., 2009). In addition, depending on the type of phenols present, rather than on the total phenol content, the intensity of bitterness of olive oils, regarded as a key acceptability attribute, can be extremely variable (high or low) (Favati et al., 2013).

Alcohol-free beers have a complex mixture of phenolic compounds extracted from malt and hops which is responsible for beer flavor and stability. The final content of phenolic components of beer depends on the raw materials and the brewing process as well. Highly flavor-active phenols may be appreciated in certain beers and in others they may be regarded as distasteful. Therefore, some studies try to find rapid analytical methods for the quality control department of beer producers to evaluate phenolic compounds that may adversely affect beer flavor and stability, what is of practical interest (Alonso García et al., 2004).

Phenolic compounds are secondary metabolites naturally present in wine grapes and/or produced during wine making process (Kelebek et al., 2010). Phenolic compounds are very important quality parameters of wines because of their impact on color, flavor and health properties, and together with polysaccharides, they contribute to the chemical stability and sensory perception of the products. Usually, the wines of greater commercial value, with the best visual and gustatory scores, coincided with higher levels of the phenolic parameters (Fanzone et al., 2012).

Wine consumption has mostly a hedonic objective, which implies that wine sensory properties play an outstanding role on wine quality perception and the importance of both volatile and non-volatile molecules in wine sensory properties has been especially demonstrated in works dealing with sensory interactions. These studies have shown that sensory properties of wine are the result of the perceptual interactions between sense modalities and/or interactions between wine molecules. More specifically, it has been demonstrated that wine astringency is driven by polymeric proanthocyanins and by certain phenolic acids and there are extremely complex interactions between non-volatile compounds on the in-mouth sensory perception. Also remarkable is the sweetness $\mathrm{x}$ astringent interaction and the matrix-dependence of the sensory responses elicited by flavonols (Sáenz-Navajas et al., 2012).

Phenolic compounds are one of the most important wine quality parameters. Amongst others, phenolic compounds have been reported as a relevant criterion for vintage differentiation, for Bordeaux CarbernetSauvignon and Merlot wines. For both wines, phenolic compounds were positively correlated with astringency (Chira et al., 2011). The intensity of perceived astringency is an important determinant of consumer response to red wine (Condelli et al., 2006). Studies addressing acceptance of astringency indicate that this is perceived as a negative attribute. On the other hand, this sensation enhances the complexity and palate-length of high quality wines.

Cadot et al. (2012) evaluated the relationship between the sensory profile of wines and the ripening stage of the grapes (harvest date) and the extraction time (duration of maceration). Astringency, bitterness, color intensity and alcohol significantly increased with ripening and astringency and color intensity increased with maceration time. Authors reported that the high impact of harvest date on the sensory profiles could be due to changes in anthocyanin and sugar contents, but also to an evolution of proanthocyanidins. In this study, authors confirmed the importance of phenolic compounds for typicality of wines.

Another important point relating wine flavor and phenolic compounds is the strain of the yeast used to ferment the must. Locally-selected yeast can affect the fermentation and influence the volatile and phenolic 
profile of white wines (Carrascosa et al., 2012). Changes in the phenolic composition in grape seeds during ripening follow changes in tannic intensity and astringency which tend to be reduced as the maturity degree increases while hardness of the seed shows a contrary trend (Ferrer-Gallego et al., 2010).

The color of red wines is one of the most important characteristics and it is the first attribute assessed by consumers during the tasting. The color of wine reflects some of its virtues and defects, its age and whether it has been submitted to a specific aging process (Marquez et al., 2014). The kind of aging (in new barrels or with oak chips) leads to significant differences in phenolic composition (Ortega-Heras et al., 2010). During the storage time, reactions may alter the color but also reduce astringency and bitterness, thereby leading to softer tasting wines. The storage of sweet red wines in bottle for a year caused the degradation of monomeric anthocyanins and the completely disappearance of most of them between 6 and 9 months. The decrease in the contents of these compounds was a result of various gradual reactions leading to more stable oligomers and polymers, and other yielding anthocyanin derivatives such as pyranoanthocyanins and methylmethine-mediated condensation adducts. These changes in anthocyanin compounds caused the red color of the young wines to evolve to browner hues as storage time increased (Marquez et al., 2014).

Phenolic compounds also have a variable impact on the volatility of aroma compounds and their sensory perception. In addition, the polarity of phenolic and volatile compounds as well as their spatial conformation influenced the interaction strength. The aroma-polyphenol interactions that could occur in wine appear to be complex and specific of the non-volatile matrix composition. Regarding anthocyanins, phenol-based flavor compounds (vanillin, syringaldehyde) led to interactions through copigmentation (Lorrain et al., 2013).

\section{CONCLUSION}

Studies with phenolic compounds have increasingly advanced in depth and complexity with regard to the elucidation of chemical structures by the application of more solid and modern techniques. These advances allow better understanding of plant metabolism and the processes of synthesis and degradation of the compounds due to genetics, pre and post-harvest, culinary and industrial factors. The comprehension of the biological mechanisms involved in the preventive action of these compounds on many chronic diseases must be elucidated to demonstrate their wide range of functions, many of which unrelated to the ability to absorb free radicals.
These studies may affect legislation and regulation of the health claims of phenolics-rich and antioxidants food. Finally, understanding the sensory impact of these substances is essential for strategies that aims at increasing the consumption of phenolic-rich fruit and vegetables, since color, bitterness and astringency, properties associated with these compounds, are sensory attributes that may affect the acceptance of food.

\section{REFERENCES}

Abdalla S, Pizzi A, Ayed N, Charrier F, Bahabri F \& Ganash A (2014) MALDI-TOF and 13C NMR analysis of Tunisian Zizyphus jujuba root bark tannins. Industrial Crops and Products, 59:277-281.

Agcam E, Akyýldýz A \& Evrendilek G (2014) Comparison of phenolic compounds of orange juice processed by pulsed electric fields (PEF) and conventional thermal pasteurisation. Food Chemistry, 143:354-361.

Agostini-Costa TS, Lima A \& Lima MV (2003) Determinação de taninos em pedúnculo de caju: método da vanilina versus método do butanol ácido. Quimica Nova, 26:763-765.

AgricResServ (2004) US Department of Agriculture, Agricultural Research Service. USDA database on the proanthocyanidin content of selected foods, Release 2004.Retrieved April 2nd 2009 from the Nutrient Data Laboratory. Available at: < http://www.ars.usda.gov/ nutrientdata>. Accessed in: July, 2014.

AgricResServ (2007) US Department of Agriculture, Agricultural Research Service.USDA database for the oxygen radical absorbance capacity (ORAC) of selected foods, Release 2007. Retrieved April 2nd 2009 from the Nutrient Data Laboratory Available at:<http:// www.ars.usda.gov/Services/docs.htm?docid=15866>. Accessed in: July, 2014.

AgricResServ (2008) US Department of Agriculture, Agricultural Research Service. USDA Iowa State University database on the isoûavone content of foods, Release 2.0-2008. Retrieved July 132014 from the Nutrient Data Laboratory Available at: <http:// www.ars.usda.gov/nutrientdata>. Accessed in: July, 2014.

AgricResServ (2010) US Department of Agriculture, Agricultural Research Service. USDA database for the oxygen radical absorbance capacity (ORAC) of selected foods, Release 2 2010. Retrieved July 132014 from the Nutrient Data Laboratory Home Page: Available at: <http://www.ars.usda.gov/Services/docs.htm?docid=15866>. Accessed in: July, 2014.

Aherne SA \& O'brien NM (2002) Dietery flavonols: chemistry, food content, and, metabolism. Nutrition, 18:75-81.

Alonso AM, Dominguez C, Guillen DA \& Barroso CG (2002) Determination of antioxidant activity of wine byproducts and its correlation with polyphenolic content. Journal of Agriculture and Food Chemistry, 50:5832-5836.

Alonso García A, Cancho Grande B \& Simal Gándara J (2004) Development of a rapid method based on solid-phase extraction and liquid chromatography with ultraviolet absorbance detection for the determination of polyphenols in alcohol-free beers. Journal of Chromatography A, 1054:175-180.

Andersen OM \& Jordheim M (2006) The anthocyanins. In: Andersen OM \& Markham KR (Eds.) Flavonoids: chemistry, biochemistry and applications. Boca Raton, CRC Press p.471-553.

Aruoma O I (2003) Methodological considerations for characterizing potential antioxidant actions of bioactive components in plant foods. Mutation Research, 523/524:09-20. 
Apak R, Güçlü K, Özyürek M \& Karademir SE (2004) Novel Total Antioxidant Capacity Index for Dietary Polyphenols and Vitamins C and E, Using Their Cupric Ion Reducing Capability in the Presence of Neocuproine: CUPRAC Method. Journal of Agricutural and Food Chemistry 52:7970-7981.

Baeza G, Amigo-Benavent M, Sarriá B, Goya L, Mateos R \& Bravo L (2014) Green coffee hydroxycinnamic acids but not caffeine protect human HepG2 cells against oxidative stress. Food Research International, 62:1038-1046.

Bajoub A, Carrasco-Pancorbo A, Ajal E, Ouazzani N \& FernándezGutiérrez A (2015) Potential of LC-MS phenolic profiling combined with multivariate analysis as an approach for the determination of the geographical origin of north Moroccan virgin olive oils. Food Chemistry, 166:292-300.

Balasundram N, Sundram K \& Samman S (2006) Phenolic compounds in plants and agri-industrial by-products: Antioxidant activity, occurrence, and potential uses. Food Chemistry, 99:191-203.

Ballus CA, Meinhart AD, Campos Jr F, da Silva L, de Oliveira A \& Godoy H (2014) A quantitative study on the phenolic compound, tocopherol and fatty acid contents of monovarietal virgin olive oils produced in the southeast region of Brazil. Food Research International, 62:74-83

Bate-Smith E \& Swein T (1962) Flavonoid compounds. In: Mason S \& Florkin A (Eds.) Comparative Biochemistry. New York, Academic Press. p.755-809.

Battestin V, Matsuda L \& Macedo G (2004) Fontes e aplicações de taninos e tanases nos alimentos. Alimentos e Nutrição, 15:63-72.

Bautista-Ortín A, Cano-Lechuga M, Ruiz-García Y \& Gómez-Plaza E (2014) Interactions between grape skin cell wall material and commercial enological tannins. Practical implications.Food Chemistry, 152:558-565.

Bavaresco L (2003) Role of viticultural factors on stilbene concentrations of grapes and wine. Drugs under Experimental and Clinical Research, 29:181-187.

Benzie IFF \& Strain JJ (1996) The ferric reducing ability of plasma (FRAP) as a measure of "antioxidant power": The FRAP assay. Analytical Biochemistry, 239:70-76.

Birch GG \& Ogunmoyela G (1980) Taste properties of cocoa drinks with an added bitter/sweet sugar: intensity/time effects. International Journal of Food Science \& Technology, 15:549-555.

Blanda G, Cerretani L, Bendini A, Cardinali A, Scarpellini A \& Lercker G (2008) Effect of vacuum impregnation on the phenolic content of Granny Smith and Stark Delicious frozen apple cvv. European Food Research and Technology, 226:1229-1237.

Blanda G, Cerretani L, Cardinali A, Barbieri S, Bendini A \& Lercker G (2009) Osmotic dehydrofreezing of strawberries: Polyphenolic content, volatile profile and consumer acceptance. LWT - Food Science and Technology, 42:30-36.

Brand-Wiliams W, Cuvelier ME \& Berset C (1995) Use of a free radical method to evaluate antioxidant activity. Food Science and Technology, 28:25-30.

Bravo L (1998) Polyphenols: chemistry, dietary sources, metabolism, and nutritional significance. Nutrition Review, 56:317-33.

Broadhurst RB \& Jones WT (1978) Analysis of condensed tannins using acidified vanillin. Journal of the Science of Food and Agriculture, 29:788-794.

Brunschwig C, Senger-Emonnot P, Aubanel ML, Pierrat A, George G, Rochard S \& Raharivelomanana P (2012) Odor-active compounds of Tahitian vanilla flavor. Food Research International, 46:148-157.

Bureau S, Renard C, Reich M, Ginies C \& Audergon J (2009) Change in anthocyanin concentrations in red apricot fruits during ripening. Food Science and Technology, 42:372-377.
Burns J, Gardner PT, Matthews D, Duthie GG, Lean MEJ \& Crozier A (2001) Extraction of phenolics and changes in antioxidant activity of red wines during vinification. Journal of Agricutural and Food Chemistry, 49:5797-5808.

Büyükbalci A \& Nehir E (2008) Determination of In Vitro Antidiabetic Effects, Antioxidant Activities and Phenol Contents of Some Herbal Teas. Plant Foods in Human Nutrition, 63:27-33.

Cadot Y, Caillé S, Samson A, Barbeau G \& Cheynier V (2012) Sensory representation of typicality of Cabernet franc wines related to phenolic composition: Impact of ripening stage and maceration time. Analytica Chimica Acta, 732:91-99.

Calvino AM, García-Medina MR \& Cometto-Muniz JE (1990) Interactions in caffeine-sucrose and coffee-sucrose mixtures: evidence of taste and flavor suppression. Chemical Senses, 15:505-519.

Cao G, Alessio HM \& Cutler RG (1993) Oxygen-radical absorbance capacity assay for antioxidants. Free Radical Biology and Medicine, 14:303-311.

Capocasa F, Scalzo J, Mezzetti B \& Battino M (2008) Combining quality and antioxidant attributes in the strawberry: The role of genotype. Food Chemistry, 111:872-878.

Carrascosa AV, Bartolome B, Robredo S, Leon A, Cebollero E, Juega M, Nunez YP, Martinez MC \& Martinez-Rodriguez AJ (2012) Influence of locally-selected yeast on the chemical and sensorial properties of Albariño white wines. LWT - Food Science and Technology, 46:319-325.

Castañeda-Ovando A, Pacheco-Hernándes M, Páez-Hernández M, Rodríguez J \& Galán-Vidal C (2009) Chemical studies of anthocyanins: A review. Food Chemistry, 113:859-871.

Condelli N, Dinnella C, Cerone A, Monteleone E \& Bertuccioli M (2006) Prediction of perceived astringency induced by phenolic compounds II: Criteria for panel selection and preliminary application on wine samples. Food Quality and Preference, 17:96-107.

Cordenunsi BR, Genovese MI, Nascimento J, Hassimoto N, Santos R \& Lajolo F M (2005) Effects of temperature on the chemical composition and antioxidant activity of three strawberry cultivars. Food Chemistry, 93:113-121.

Cox DN, Melo L, Zabaras D \& Delahunty CM (2012) Acceptance of health-promoting Brassica vegetables: the influence of taste perception, information and attitudes. Public Health Nutrition, 15:1474-1482.

Crozier A, Burns J, Aziz A, Stewart A, Rabias Z, Jenkins G, Edwards C \& Lean M (2000) Antioxidant flavonols from fruits, vegetables and beverages: measurements and bioavailability. Biology Research, 33:79-88.

Chira K, Pacella N, Jourdes M \& Teissedre PL (2011) Chemical and sensory evaluation of Bordeaux wines (Cabernet-Sauvignon and Merlot) and correlation with wine age. Food Chemistry, 126:1971-1977.

D’Archivio M, Filesi C, Di Benedetto R, Gargiulo R, Giovannini C \& Masella R (2007) Polyphenols, dietary sources and bioavailability. Annali dell'Istituto Superiore di Sanità, 43:348-361.

Delmas D, Lancon A, Colin D, Jannin B \& Latruffe N (2006) Resveratrol as a chemopreventive agent: A promising molecule for fighting cancer. Current Drug Targets, 7:423-442.

Dignum MJW, Van der Heijden R, Kerler J, Winkel C \& Verpoorte R (2004) Identification of glucosides in green beans of Vanilla planifolia Andrews and kinetics of vanilla â-glucosidase. Food Chemistry, 85:199-205.

Ding Y, Dai X, Zhang Z, Jiang Y, Ma X, Cai X \& Li Y (2014) Proanthocyanidins protect against early diabetic peripheral neuropathy by modulating endoplasmic reticulum stress. Journal of Nutritional Biochemistry, 25:765-772. 
Ding Y, Zhang Z, Dai X, Jiang Y, Bao L \& Li Y (2013) Grape seed proanthocyanidins ameliorate pancreatic beta-cell dysfunction and death in low-dose streptozotocin- and high-carbohydrate/high-fat diet-induced diabetic rats partially by regulating endoplasmic reticulum stress. Nutrition \& Metababolism,10:01-12.

Dixon R A \& Paiva NL (1995) Stress-Induced phenylpropanoid metabolism. The Plant Cell, 7:1085-1097.

El Gharras H (2009) Polyphenols: food sources, properties and applications - a review. International Journal of Food Science \& Technology, 44:2512-2518.

Erlund I (2004) Review of the flavonoids quercetin, hesperetin, and naringenin. Dietary sources, bioactivities, bioavailability, and epidemiology. Nutrition Research 24:851-874.

Esti M, Contini M, Moneta E \& Sinesio F (2009) Phenolics compounds and temporal perception of bitterness and pungency in extra-virgin olive oils: Changes occurring throughout storage. Food Chemistry, 113:1095-1100

Fanzone M, Peña-Neira A, Gil M, Jofré V, Assof M \& Zamora F (2012) Impact of phenolic and polysaccharidic composition on commercial value of Argentinean Malbec and Cabernet Sauvignon wines. Food Research International, 45:402-414

Favati F, Condelli N, Galgano F \& Caruso MC (2013) Extra virgin olive oil bitterness evaluation by sensory and chemical analyses. Food Chemistry, 139:949-954.

Ferrer-Gallego R, García-Marino M, Hernández-Hierro M, Rivas-Gonzalo JC \& Escribano-Bailón TM (2010) Statistical correlation between flavanolic composition, colour and sensorial parameters in grape seed during ripening. Analytica Chimica Acta, 660:22-28.

Flores G, Moreno F, Blanch G \& Castillo M (2014) Phenylalanine ammonia-lyase, flavanone 3b-hydroxylase and flavonol synthase enzyme activity by a new in vitro assay method in berry fruits Phenylalanine ammonia-lyase, flavanone 3 b-hydroxylase and flavono synthase enzyme activity by a new in vitro assay method in berry fruits. Food Chemistry, 153:130-133

Folin O \& Denis W (1912) On phosphotungstic-phosphomolvbdic compounds as color reagents. Journal of Biological Chemistry, 12:239-43.

Fontoin H, Saucier C, Teissedre PL \& Glories Y (2008) Effect of pH, ethanol and acidity on astringency and bitterness of grape seed tannin oligomers in model wine solution. Food Quality and Preference, 19:286-291.

Franco MN, Galeano-Díaz T, López O, Fernández-Bolaños J, Sánchez J, De Miguel C, Gil MV \& Martín-Vertedor D (2014) Phenolic compounds and antioxidant capacity of virgin olive oil. Food Chemistry, 163:289-298.

Fridovich I (1998) Oxygen toxicity: a radical explanation. The Journal of Experimental Biology, 201:1203-1209.

Gallardo C, Jiménez L \& García-Conesa MT (2006) Hydroxycinnamic acid composition and in vitro antioxidant activity of selected grain fractions. Food Chemistry, 99:455-463.

García-Lafuente A, Moro C, Manchón N, Gonzalo-Ruiz A, Guillamón A, Rostagno M \& Mateo-Vivarachoet L (2014) In vitro anti-inflammatory activity of phenolic rich extracts from white and red common beans. Food Chemistry, 161:216-223.

García-Mesa JA, Pereira-Caro G, Fernández-Hernández A, GarcíaOrtíz C \& Mateos R (2008) Influence of lipid matrix in the bitterness perception of virgin olive oil. Food Quality and Preference, 19:421-430.

Gerstenmeyer E, Reimer S, Berghofer E, Schwartz H \& Sontag G (2013) Effect of thermal heating on some lignans in flax seeds, sesame seeds and rye. Food Chemistry, 138:1847-1855.
Girennavar B, Jayaprakasha GK, Mclin SE, Maxim J, Yoo KS \& Patil BS (2008) Influence of Electron-Beam Irradiation on Bioactive Compounds in Grapefruits (Citrus paradisi Macf.). Journal of Agriculture and Food Chemistry, 56:10941-10946.

Gonçalves J, Silva C, Castilho P \& Câmara J (2013) An attractive, sensitive and high-throughput strategy based on microextraction by packed sorbent followed by UHPLC-PDA analysis for quantification of hydroxybenzoic and hydroxycinnamic acids in wines. Microchemical Journal, 106:129-138.

Grace MH, Warlick CW, Neff S A \& Lila MA(2014) Efficient preparative isolation and identification of walnut bioactive components using high-speed counter-current chromatography and LC-ESI-IT-TOF-MS. Food Chemistry, 158:229-238.

Graf B, Milbury P \& Blumberg J (2005) Flavonols, Flavones, Flavanones, and Human Health: Epidemiological Evidence. Journal of medicinal food, 8:281-290.

Haddock E, Gupta R, Al-Shafi S, Leydon K \& Haslam E (1982) The metabolism of gallic acid and hexahydroxydiphenic acid in plants: biogenics and molecular taxonomic considerations. Phytochemistry, 21:1049-1062.

Häkkinen S (2000) Flavonols and Phenolic Acids in Berries and Berry Products. Doctoral dissertation.Faculty of Medicine / University of Kuopio. Kuopio. 221p.

Halliwell B (2007) Oxidative stress and cancer: have we moved forward? Journal of Biochemistry, 401:01-11.

Haslam E (1982) The metabolism of gallic acid and hexahydroxydiphenic acid in higher plants. Progress in the Chemistry of Organic Natural Products, 41:01-46.

He J \& Giusti M (2010) Anthocyanins: Natural Colorants with HealthPromoting Properties. Annual Review of Food Science and Technology, 1:163-87.

He D, Shan Y, Wu Y, Liu G \& Chen B (2011) Simultaneous determination of flavanones, hydroxycinnamic acids and alkaloids in citrus fruits by HPLC-DAD-ESI/MS. Food Chemistry, 127:880-885.

Horst MA \& Lajolo FM (2007) Biodisponibilidade de compostos bioativos de alimentos. In: Cozzolino S (Eds.) Biodisponibilidade de Nutrientes. $2^{\text {a }}$ ed. São Paulo, Manole. p.697-731.

Ibrahim M, Abu-Reidah, Arráez-Román D, Segura-Carretero A \& Fernández-Gutiérrez A (2013) Extensive characterisation of bioactive phenolic constituents from globe artichoke (Cynara scolymus L.) by HPLC-DAD-ESI-QTOF-MS. Food Chemistry, 141:2269-2277.

Ignat I, Volf I \& Popa V (2011) A critical review of methods for characterisation of polyphenolic compounds in fruits and vegetables. Food Chemistry, 126:1821-1835.

Inarejos-Garcia AM, Androulaki A, Salvador MD, Fregapane G \& Tsimidou MZ (2009) Discussion on the objective evaluation of virgin olive oil bitterness. Food Research International, 42:279-284.

Kelebek H, Canbas A, Jourdes M \& Teissedre PL (2010) Characterisation of colored and colorless phenolic compounds in Öküzgözü wines from Denizli and Elazig regions using HPLC-DAD-MS. Industrial Crops and Products, 31:499-508.

Klejdus B, Vacek J, Benešova L, Kopecky’ J, Lapc;ik O \& Kuban; V (2007) Rapidresolution HPLC with spectrometric detection for the determination and identification of isoflavones in soy preparations and plant extracts. Analytical and Bioanalytical Chemistry, 389:2277-2285.

Konczak I \& Zhang W (2004) Anthocyanins-more than nature colours. Journal of Biomedicine and. Biotechnology, 5:239-240.

Kong J, Chia L, Goh N, Chia T \& Brouillard R (2003) Analysis and biological activities of anthocyanins. Phytochemistry, 64:923-933. 
Koolen H, da Silva F, Gozzo F, de Souza A \& de Souza A (2013) Antioxidant, antimicrobial activities and characterisation of phenolic compounds from buriti (Mauritia flexuosa L. f.) by UPLC-ESI-MS/ MS. Food Research International, 5:467-473.

Koseki T, Mihara K, Murayama T \& Shiono Y (2010) A novel Aspergillus oryzae esterase that hydrolyzes 4-hydroxybenzoic acid esters. FEBS Letters, 584:4032-4036.

Laaksonen O, Sandell M, Järvinen R \& Kallio H (2011) Orosensory contributing compounds in crowberry (Empetrum nigrum) pressbyproducts. Food Chemistry, 124:1514-1524.

Laaksonen O, Sandell M \& Kallio H (2010) Chemical factors contributing to orosensory profiles of bilberry (Vaccinium myrtillus) fractions. European Food Research and Technology, 231:271-285.

Laaksonen O, Sandell M, Nordlund E, Heiniö R, Malinen H, Jaakkola M \& Heikki Kallio (2012) The effect of enzymatic treatment on blackcurrant (Ribes nigrum) juice flavour and its stability. Food Chemistry, 130:31-41

Landete J (2011) Ellagitannins, ellagic acid and their derived metabolites A review about source, metabolism, functions and health. Food Research International, 44:1150-1160.

Lapornik B, Golc Wondra A \& Prosiek M (2004) Comparison of TLC and spectrophotometric methods for evaluation of the antioxidant activity of grape and berry anthocyanins. Journal of Planar Chromatography, 17:207-212

Lee J \& Rennaker C (2007) Antioxidant capacity and stilbene contents of wines produced in the Snake River Valley of Idaho. Food Chemistry 105:195-203

Leem E, Nam J, Jeon M, Shin W, Won S, Park S, Choi M, Jin B, Jung U \& Kim S (2014) Naringin protects the nigrostriatal dopaminergic projection through induction of GDNF in a neurotoxin model of Parkinson's disease. Journal of Nutritional Biochemistry, 25:801-806.

Lesschaeve I \& Noble A C (2005). Polyphenols: factors influencing their sensory properties and their effects on food and beverage preferences. The American Journal of Clinical Nutrition, 81:330S-335S.

Lorrain B, Tempere S, Iturmendi N, Moine V, de Revel G \& Teissedre PL (2013) Influence of phenolic compounds on the sensorial perception and volatility of red wine esters in model solution: An insight at the molecular level. Food chemistry, 140:76-82.

Lu X, Wang J, Al-Qadiri H, Ross C, Powers J, Tang J \& Rasco B (2011) Determination of total phenolic content and antioxidant capacity of onion (Allium cepa) and shallot (Allium oschaninii) using infrared spectroscopy. Food Chemistry, 129:637-644.

Macheix J, Fleuriet A \& Billot J (1990) Fruit Phenolics. Boca Raton, CRC Press. p. 126.

Marmet C, Actis-Goretta L, Renouf M \& Giuffrida F (2014) Quantification of phenolic acids and their methylates, glucuronides, sulfates and lactones metabolites in human plasma by LC-MS/MS after oral ingestion of soluble coffee. Journal of Pharmaceutical and Biomedical Analysis, 88:617-625.

Marquez A, Serratosa MP \& Merida J (2014) Influence of bottle storage time on colour, phenolic composition and sensory properties of sweet red wines. Food Chemistry, 146:507-514.

Mateos R, Lecumberri H, Ramos S, Goya L \& Bravo L (2005) Determination of malondialdehyde (MDA) by high-performance liquid chromatography in serum and liver as a biomarker for oxidative stress Application to a rat model for hypercholesterolemia and evaluation of the effect of diets rich in phenolic antioxidants from fruits. Journal of Chromatography B, 827:76-82.

McCarthy AL, O'Callaghan YC, Connolly A, Piggott CO, FitzGerald RJ \& O'Brien MN (2012) Phenolic extracts of brewers' spent grain (BSG) as functional ingredients -Assessment of their DNA protective effect against oxidant-induced DNA single strand breaks in U937 cells. Food Chemistry, 134:641-646.
Milenkovic D, Deval C, Dubray C, Mazur A \& Morand C (2011) Hesperidin Displays Relevant Role in the Nutrigenomic Effect of Orange Juice on Blood Leukocytes in Human Volunteers: A Randomized Controlled Cross-Over Study. PLoS One, 6:26669.

Miller HE (1971) A simpliûed method for the evaluation of antioxidants. Jounal of the American Oil Chemist's Society, 48:91-92.

Miller NJ \& Rice-Evans CA (1997) Factors inûuencing the antioxidant activity determined by the ABTSd+ radical cation assay. Free Radical Research, 26:195-199.

Mujic' A, Grdovic' M, Mujic' M, Mihailovic' M, $Z_{i}$ ivkovic' J, Poznanovic'G \& Vidakovic M (2011) Antioxidative effects of phenolic extracts from chestnut leaves, catkins and spiny burs in streptozotocin-treated rat pancreatic b-cells. Food Chemistry, 125:841-849.

Naczk M \& Shahidi F (2004) Extraction and analysis of phenolics in food. Journal of Chromatography A, 1054:95-111.

Narváez-Cuenca C, Vincken JP, Zheng C \& Gruppen H (2013) Diversity of (dihydro) hydroxycinnamic acid conjugates in Colombian potato tubers. Food Chemistry, 139:1087-1097.

Noratto G, Porter W, Byrne D \& Cisneros-Zevallos L (2009) Identifying peach and plum polyphenols with chemopreventive potential against estrogen-independent breast cancer cells. Journal of Agricultural and Food Chemistry, 57:5219-5226.

Noratto G, Porter W, Byrne D \& Cisneros-Zevallos L (2014) Polyphenolics from peach (Prunus persica var. Rich Lady) inhibit tumor growth and metastasis of MDA-MB-435 breast cancer cells in vivo. Journal of Nutritional Biochemistry, 25:796-800.

Nordlund E, Heiniö RL, Viljanen K, Pihlava JM, Lehtinen P \& Poutanen K (2013) Flavour and stability of rye grain fractions in relation to their chemical composition. Food Research International, 54:48-56.

Ortega-Heras M, Pérez-Magariño S, Cano-Mozo E \& González-San JML (2010) Differences in the phenolic composition and sensory profile between red wines aged in oak barrels and wines aged with oak chips. LWT - Food Science and Technology, 43:1533-1541

Ough CS \& Amerine MA (1988) Methods for analysis of musts and wines. New York, Wiley-Interscience. 377p

Ouni Y, Taamalli A, Gómez-Caravaca AM, Segura-Carretero A, FernándezGutiérrez A \& Zarrouk M (2011) Characterization and quantification of phenolic compounds of extra-virgin olive oils according to their geographical origin by a rapid and resolutive LC-ESI-TOF MS method. Food Chemistry, 127:1263-1267.

Pandey K \& Rizvi S (2009) Anti-oxidative action of resveratrol: Implications for human health. Arabian Journal of Chemistry, 4:293-298.

Pietta P (2000) Flavonoids as antioxidants. Journal of Natural Products, 63:1035-1042.

Pineli LLO, Moretti CL, dos Santos MS, Campos AB, Brasileiro AV, Córdova A C \& Chiarello MD (2011a) Antioxidants and other chemical and physical characteristics of two strawberry cultivars at different ripeness stages Journal of Food Composition and Analysis, 24:11-16

Pineli LLO, Moretti CL, Rodrigues J, Ferreira D \& Chiarello MD (2011b) Variations in antioxidant properties of strawberries grown in Brazilian savannah and harvested in different seasons. Journal of the Science of Food and Agriculture, 92:831-838.

Pineli LLO, Moretti CL \& Chiarello MD (2012) Quality, bioactive compounds and antioxidant activity of strawberries grown in the Brazilian savannah and stored at different temperatures. Journal of Food, Agriculture \& Environment, 10:165-171.

Pinto MS, Lajolo FM \& Genovese MI (2007) Bioactive Compounds and Antioxidant Capacity of Strawberry Jams. Plant Foods for Human Nutrition (Dordrecht), 63:127-131. 
Pinto M S, Lajolo F M \& Genovese M I (2008) Bioactive compounds and quantification of total ellagic acid in strawberries (Fragaria $x$ ananassa Duch.). Food Chemistry, 107:1629-1635.

Podsêdek A, Sosnowska D \& Anders B (2003) Antioxidative capacity of tomato products. European Food Research and Technology, 217:296-300

Porter LJ (1989) Tannins. In: Harborne J (Ed.) Methods in plant biochemistry- Plant phenolics. London, Academic Press. p. 389-419.

Rahman I, Biswas SK \& Kirkham PA (2006) Regulation of inflammation and redox signaling by dietary Polyphenols. Biochemical Pharmacology, 72:1439-1452.

Razzaghi-As N, Garrido J, Khazraei H, Borges F \& Firuzi O (2013) Antioxidant Properties of Hydroxycinnamic Acids: A Review of Structure-Activity Relationships. Current Medicinal Chemistry, 20:123-135.

Rein M (2005) Copigmentation reactions and color stability of berry anthocyanins. Academic dissertation. University of Helsinki, Helsinki. $87 \mathrm{p}$.

Ribas-Agustí A, Gratacós-Cubarsí M, Sárraga C, Guàrdia MD, GarcíaRegueiro JA \& Castellari M (2014) Stability of phenolic compounds in dry fermented sausages added with cocoa and grape seed extracts. LWT - Food Science and Technology, 57:329-336.

Rice-Evans CA, Miller NJ \& Paganga G (1996) Free Radical Biology \& Medicine, 20:933-956.

Robbers J, Speedie M \& Tylerv E (1996) Pharmacognosy and Pharmacobiotechnology. Baltimore, Williams \& Wilkins. 14p.

Robbins R J (2003) Phenolic acids in foods: An overview of analytical methodology. Journal of Agricultural and Food Chemistry, 51:28662887.

Rodríguez-Rivera M, Lugo-Cervantes E, Winterhalter P \& Jerz G (2014) Metabolite profiling of polyphenols in peels of Citrus limetta Risso by combination of preparative high-speed countercurrent chromatography and LC-ESI-MS/MS. Food Chemistry, 158:139-152.

Rothwell J A, Pérez-Jiménez J, Neveu V, Medina-Ramon A, M’Hiri N, Garcia Lobato P, Manach C, Knox K, Eisner R, Wishart D \& Scalbert A (2013) Phenol-Explorer 3.0: a major update of the Phenol-Explorer database to incorporate data on the effects of food processing on polyphenol content. Available at: http://www.phenol-explorer.eu/> . Acessed in: July, 2014.

Sáenz-Navajas MP, Avizcuri JM, Ferreira V \& Fernández-Zurbano P (2012) Insights on the chemical basis of the astringency of Spanish red wines. Food Chemistry, 134:1484-1493.

Santos RI (2007) Metabolismo básico e origem dos metabólitos secundários. In: Simoes CM, Schenkel EP, Gosmann G, Mello JCP, Mentz LA \& Petrovick PR (Eds.) Farmacognosia, da planta ao medicamento. Florianopolis, Editora da UFSC. p.403-434.

Schmidt PC \& González-Ortega G (1993) Passionsblumenkrau Bestimmung des Gesamtflavonoidgehaltes von Passiflorae herba. Apoth-Ztg, 133:4457-4466.

Schuster B \& Herrmann K (1985) Hydroxybenzoic and hydroxycinnamic acid derivatives in soft fruits. Phytochemistry, 24:2761-2764.

Seeram NP, Lee R, Scheuller HS \& Heber D (2006) Identification of phenolic compounds in strawberries by liquid chromatographic analysis of phenolic compounds in strawberries by liquid chromatography electrospray ionization mass spectroscopy. Food Chemistry, 97:01-11.

Sellappan S, Akoh CC \& Krewer G (2002) Phenolic compounds and antioxidant capacity of Georgia-grown blueberries and blackberries Journal of Agricultural and Food Chemistry, 50:2432-2438.

Sies H (2000) Oxidative stress. In: Fink G (Ed). Encyclopedia of Stress. San Diego, Academic press. p.102-105.
Siger A, Czubinski J, Kachlicki P, Dwiecki K, Lampart-Szczapa E \& Nogala-Kalucka M (2012) Antioxidant activity and phenolic content in three lupin species. Journal of Food Composition and Analysis, 25:190-197.

Simirgiotis M, Bórquez J \& Schmeda-Hirschmann G (2013) Antioxidant capacity, polyphenolic content and tandem HPLC-DAD-ESI/MS profiling of phenolic compounds from the South American berries Luma apiculata and L. chequén. Food Chemistry, 139:289-299.

Singleton VL \& Rossi Jr JA (1965) Colorimetry of total phenolics with phosphomolybdic phosphotungstic acid reagents. American Journal of Enology and Viticculture, 16:144-158.

Singleton VL (1974) Analytical fractionation of the phenolic substances of grapes and wine and some practical uses of such analyses. American Chemical Society, 137:184-211.

Smeds AI, Eklund PC, Sjoholm RE, Willfor SM , Nishibe S, Deyama T \& Holmbom BR (2007) Quantification of a Broad Spectrum of Lignans in Cereals, Oilseeds, and Nuts. Journal of Agricultural and Food Chemistry, 55:1337-1346.

Soares S, Kohl S, Thalmann S, Mateus N, Meyerhof W \& De Freitas V (2013) Different Phenolic Compounds Activate Distinct Human Bitter Taste Receptors. Journal of Agricultural and Food Chemistry, 61:1525-1533.

Strack D (1997) Phenolic metabolism. In: Dey P \& Harbourne J (Eds.) Plant Biochemistry. San Diego, Academic Press. p.387-416.

Su D, Ti H, Zhang R, Zhang M, Wei Z, Deng Y \& Guo J (2014) Structural elucidation and cellular antioxidant activity evaluation of major antioxidant phenolics in lychee pulp. Food Chemistry, 158:385-391.

Tarascou I, Mazauric J, Meudec E, Souquet J, Cunningham D, Nojeim S, Cheynier V \& Fulcrand H (2011) Characterisation of genuine and derived cranberry proanthocyanidins by LC-ESI-MS. Food Chemistry, 128:802-810.

Troszyñska A, Estrella I, Lamparski G, Hernández T, Amarowicz R \& Pegg R B (2011) Relationship between the sensory quality of lentil (Lens culinaris) sprouts and their phenolic constituents. Food Research International, 44:3195-3201.

Tsao R \& Yang R (2003) Optimization of a new mobile phase to know the complex and real polyphenolic composition: towards a total phenolic index using high-performance liquid chromatography. Journal of Chromatography A, 1018:29-40.

Tsopmo A, Awah F \& Kuetec V (2013) 12 - Lignans and Stilbenes from African. In: Keute V (Ed.) Medicinal Plants Pharmacology and Chemistry. London, Elsevier. p.435-478.

Vanamala J, Reddivari L, Yoo K S, Pike L M \& Patil B S (2006) Variation in the content of bioactive flavonoids in different brands of orange and grapefruit juices. Journal of Food Composition and Analysis, 19:157-166.

Vattem DA \& Shetty K (2005) Biological functionality of ellagic acid: a review. Journal of Food Biochemistry, 29:234-266.

Vedana MIS (2008) Efeito do processamento na atividade antioxidante de uva. Master's thesis. University of Paraná, Curitiba. 87p.

Vogt T (2010) Phenylpropanoid Biosynthesis. Molecular Plant, 3:02-10.

Wayner DDM, Burton GW, Ingold KU \& Locke S (1985) Quantitative measurement of the total, peroxyl radical-trapping antioxidant capability of human blood plasma by controlled peroxidation: The important contribution made by plasma proteins. Febs Letters, 187:33-37.

Weber F, Greve K, Durner D, Fischer U \& Winterhalter P(2013) Sensory and Chemical Characterisation of Phenolic Polymers from Red Wine Obtained by Gel Permeation Chromatography. American Journal of Enology and Viticulture, 64:15-25. 
Wen L, Wu D, Jiang Y, Prasadd K, Lin S, Jiang G, He J, Zhao M, Luo W \& Yang B (2014) Identification of flavonoids in litchi (Litchi chinensis Sonn.) leaf and evaluation of anticancer activities Journal of Functional Foods, 6:555-563.

Whitley A, Stoner G, Darby M \& Walle T (2003) Intestinal epithelial cell accumulation of the cancer preventive polyphenol ellagic acid extensive binding to protein and DNA. Biochemical Pharmacology, 66:907-915.

Willfor S, Smeds A \& Holmboma B (2006) Chromatographic analysis of lignans. Journal of Chromatography A, 1112:64-77.
Yildirim A \& Turker A (2014) Effects of regeneration enhancers on micropropagation of Fragaria vesca $\mathrm{L}$. and phenolic content comparison of field-grown and in vitro-grown plant materials by liquid chromatography-electrospray tandem mass spectrometry (LC-ESIMS/MS). Scientia Horticulturae, 169:169-178.

Zhou X, Yan L, Yin P, Shi L, Zhang J, Liu Y \& Ma C (2014) Structural characterisation and antioxidant activity evaluation of phenolic compounds from cold-pressed Perilla frutescens var. arguta seed flour. Food Chemistry, 164:150-157. 